\title{
Ecophilosophy and the natural environment ${ }^{\star}$
}

\section{Ekofilozofia i środowisko naturalne}

\author{
Zbigniew Hull \\ University of Warmia and Mazury in Olsztyn, Poland \\ -zhull@wp.pl
}

\begin{abstract}
The article contains a semantic analysis of the terms of ecophilosophy and discusses the theme widely as well as closely presenting the relationship between a human being and the natural environment.
\end{abstract}

Keywords: ecophilosophy, semantic analysis, environmental philosophy, natural environment

Streszczenie: Artykuł zawiera analizę semantyczną pojęcia "eko-filozofia" oraz prezentuje szeroką dyskusję na temat tego zagadnienia, ukazując jednocześnie bliskie związki człowieka ze środowiskiem naturalnym.

Słowa kluczowe: ekofilozofia, analiza semantyczna, filozofia środowiskowa, środowisko naturalne

\section{Introduction}

Ecophilosophy, which can also be referred to as ecological philosophy, ecosophy, ecological humanism, environmentalism, environmental rights and sometimes practical philosophy of nature and more, is an idea that is currently grasped and cultivated in two approaches. The first approach, dominant among the participants of various environmental movements and associations and in the mass media, ecophilosophy is a loose, general reflection on existential and morally important issues that are the result of human problems (society, globalized humanity) with the natural environment. Cultivating such attitude involves demands and programs on environmental protection becoming a theoretical foundation for the ideologies of various non-governmental environmental protection organisations and the "green" parties (and then it is identified with ecology as a defined, "green" protectionist ideology, although of various axiological orientation and nuanced). Others, when speaking about ecophilosophy, have in mind a certain specific, accepted by academic standards, undertaking activities and searching for solutions for philosophical problems concerning relations and interactions between human and nature. Interpreted in such way, it becomes philosophy in an institutionalized, academic sense.

\section{Different ways of interpreting the term ecophilosophy}

Academic philosophy, as one knows, is also practised in different ways, but it is always subject to rigorous standards imposed by the academic environment, it is

" This article was originally published in Polish as Hull, Zbigniew. 2006. "Ekofilozofia i środowiska naturalne." Studia Ecologiae et Bioethicae 4: 367-376. The translation of the article into English was financed by the Ministry of Science and Higher Education of the Republic of Poland as part of the activities promoting science - Decision No. 676/P-DUN/2019 of 2 April 2019. Translation made by GROY Translations. 
intersubjectively articulated, theoretically presented and methodologically arranged. In short, one can say that it is discursively arranged, objectified result of the human pursuit for the essential, maximally general and comprehensive understanding of the world, human and the existentially important relations and interactions between them. Understanding, which (and this constitutes of peculiarity and individuality of philosophy) at the same time, is defining (naming, grasping and assigning meanings, situating in context), explaining (pointing out the universal, necessary laws and principles that constitute the foundation of existence and determine the essence of the subject) and evaluative experience of the world and one's own existence in it (existentially vital experience of the reality, expression of the awareness of being and co-existence in being, experience orienting and organizing the cognitive and practical activity of human).

While ecophilosophy was formed it was, and for some it still is, emotionally charged and explicitly defined, concerning content and axiology, philosophizing on environment protection, nature and natural connections between human and nature: the name itself clearly defined its direction, content and manner of philosophical involvement and was identified with the one, radically "green" way of understanding and human's place in it. Over the years, differences in approaches, attitudes and nuanced evaluation began to emerge. The analysed issues began to be more complex, and gradually these issues started to circulate in the professional philosophy.

At the Sixth Polish Philosophical Congress in Torun (in 1995), the section of ecophilosophy and bioethics was established. In the course of the session in this section, it was proposed that the terms ecophilosophy and philosophy of ecology should be treated as synonyms that mean a new field of discussion of philosophical inquiry. It was pointed out that based on ecophilosophy grasped in such scope, there is a possibility, and it can indeed be observed, of the existence of different views and attitudes concerning the understanding and evaluating the interdependence between human (society) and nature, views that are the expression of ontological, epistemological and axiological assumptions made, as well as individual experience and preferences (Tyburski 1996). Adopting this point of view, one should acknowledge that within the field of ecophilosophy understood in such a way, there are possible both explicit, pro-ecological (in a positive sense of the term ecological, as nature-friendly, etc.) and anti-ecological concepts (technocratic, extremely anthropocentric).

\section{An attempt to define basic terms}

In the ten years that have passed since the Sixth Polish Philosophical Congress, another, new approaches to ecophilosophy have emerged, both the scope of questions and several new proposals were developed. However, the terminological mess remains as there is still a lack of agreement on the name of this field of philosophizing and there are many different terms in use (Dołęga 2005), and one could get the impression that the status of this field of philosophizing is still being questioned by some academic representatives of philosophy.

Therefore, I believe that there is a need for meta-philosophical discussion concerning ecophilosophy that would allow us to:

- diagnose of the current status of ecophilosophy and establish what one bears in mind when using this term and to define precisely philosophy of this field;

- preliminary, as far as it is currently possible, outline, determine aspects of the field of this issue;

- determine, by analysing the applied ways and methods of philosophizing in this field, the minimum of "academic" methodological correctness;

- develop, at least for educational purposes, a preliminary proposal for a standard of understanding ecophilosophy.

I do realize that it is burdensome because the nature of philosophizing itself and lack of agreement to what philosophy is and what are the acceptable or proper methods 
of practising it among philosophers cause a lot of problems. And yet, one should take into account the dynamic nature of the human's threats and problems concerning nature and, as a consequence, the emergence of new philosophical issues related to it.

In all approaches and discussions on ecophilosophy, the natural environment is being mentioned. Usually, this term is being used without defining its scope and meaning, assuming that everyone knows how to understand it. I believe that this matter is not as simple and obvious as it seems and it requires some explanations and additions. The very concept of the environment can be understood differently. Some define it as everything, not distinguishing the core or separate entity for which this everything could be called environment. Others, realizing that the environment is always an environment of someone or something, define it with everything around it, its surroundings. Here-referring to the dictionaries of the Polish language and the study of this matter of Adam Kotarbiński (Kotarbiński 1977, 33-43; Bartkowski 1991, 47-53). I acknowledge that a distinction between environment and surroundings must be made. Speaking about the surroundings, we usually mean a set of items, relations, interactions, etc. existing around "something" (being in spatial relation with what is surrounded) and one usually does not delve into (it is not interesting) its nature, nature of the relationships of this "something" and its surroundings. Whereas, one could define the environment as "the surroundings in which the mutual conditions of existence and development of something that is surrounded and its surroundings take place" (Bartkowski 1991, 42).

In short, the environment always becomes relative to some distinguished subject/object and separated from the surroundings because of some necessary and crucial dependencies and relationships for its existence and functioning. The environment that one speaks about (natural, cultural, social, physical, biological, etc.) is determined by the properties, connections and interdependencies, and processes separated from the environment due to their importance or significance for the distinguished subject/object. One then focuses on a specific, selected type or aspect of interdependencies and relationship with the environment (on within the environment). While realizing that it is connected to other dimensions of environmental properties. And then, one takes them into account as far as they are vital from the point of view from the one interested.

Ecophilosophy focuses on the relationship between human and the natural environment. Here, I assume a colloquial understanding of the term, including in its scope only the general abiotic and biotic components shaped in the process of the evolution of the biosphere and determining the existence and functioning of human as a living being (a zoological species), but also the components of nature transformed by human activity and interacting with it ("humanized" nature). I do not use this term meaning "untouched by human hands" as there is practically no such environment on our planet. Other human environments (aspects, dimensions of its existence and functioning) are taken into account and analysed based on ecophilosophy, as far as they determine, affect the relationship between human and nature.

Human, both as an element of nature and as a transcendent subject of its theoretical and practical activity, is presented in ecophilosophical discussion in four fundamental dimensions (although most authors do not usually make this distinction, speaking of human "in general" or focusing on the human existence in a society or as a species. Firstly, one might confront human with nature as an individual, a specific representative of the homo sapiens with its bio-psychological and social properties and impact on nature. Secondly, human beings are most frequently presented as a whole species in the sense of biology, ecology and population and in this aspect, their impact on natural ecosystems is considered. One also investigates its specificity and its "species being", taking into account the social 
way of existence of the specific representatives of the species as a new quality shaped in the process of biological evolution. Thirdly, when saying "human", one means society - human societies and civilizations living in a specific natural environment and needing it for their existence, but due to sociosphere and technosphere, establishing their own laws of functioning in nature and trying to impose their "game rules". And finally, the dimension of human existence that was not revealed until the second half of the $20^{\text {th }}$ century, human as "globalized humanity", a new quality of socio-technological, still based in nature, existence. People who, although internally divided and conflicted, are dependent on each other, as a whole on a global scale, transform and degrade the Earth's biosphere to such extent that they call into question their future existence, both as a society and as a species.

In this context, one has to reflect on the difference between ecophilosophy and the search for reasons for justification the environmental protection (no one doubts that the environment must be protected, the disputes concern to what extent and how it should be performed) and discussions concerning philosophical consequences (both theoretically, for a better understanding of the world and oneself, and practically, for establishing the course of action) of existing problems of human concerning the natural environment. Can loose reflections on this subject be defined as ecophilosophy? I do not believe it can. In my opinion, after thirty years of discussing this topic, the name ecophilosophy should be reserved for methodologically structured and subject-conscious theoretical reflections and proposals. It is now possible to determine, at least roughly, the field of discussion of this philosophical inquiry and to show its aspirations and tasks and to separate it institutionally.

\section{An attempt to specify ecophilosophical issues}

Although philosophers addressing this issue focus on different aspects and sometimes differently define their subject (and often present opposing theses on a given topic), I believe that an attempt can be made to distinguish the common element of their inquiries which allows referring to the shared subject of research. That is nature and human at the same time, in their unity, interdependence and interactions considered in the context of their essence, their way of existence and cognition, their values and evaluation, their morals and the possibility of anticipating and regulating them for the good (existence) of human and the biosphere (or vice versa: the biosphere and human). The reversal of the order of the relationships contained in brackets shows that depending on the adopted hierarchy of importance ("more human" or "more natural" approach) one attitude will be characterized by more humanistic approach, more or less anthropocentric one, while the other - by biocentric, holistic or even cosmocentric one. However, regardless of one's preferences, the relations, interactions between the elements that constitute unity are the dominant, central subject of the research. It is not about nature, the biosphere or the natural environment (and its protection) as such or "in and of itself". These are the subject of natural sciences (and sozology). It is not about human either, as a human is a subject of many sciences, in various dimensions, and the question "what and who is human?" is approached and solved in various ways by philosophical anthropology.

In the ecophilosophical reflections and research one can distinguish several fields of the issue that constitute its field of discussion. These are:

1. Issues concerning both ontological status of nature (the biosphere) in the process of its creation and "humanization" by the societies as well as questions about the place and way of human existence (as an individual, species, societies, globalized humanity) in nature (the biosphere). In the current ecological condition, the answer to the question of what and who is a human being in his relations with nature is being sought and to what extent human belongs to nature and depends on it as a co-existing species (what human is) and to what extent 
and in what sense he exceeds it, transcends their own naturalness and the biosphere creating anthroposphere (who a human becomes). In this context, the issue of the existential identity of the biosphere resulting from an increase in the anthropogenic impact on the environment and decline of biodiversity ("The Holocene extinction" leading to a change of direction of the evolution of the biosphere) becomes particularly relevant. The question about the prospects for the future development of globalized humanity in conditions of progressive degradation of the natural environment becomes even more dramatic.

2. Axiology reflections concerning both nature itself and its various elements (ecosystems, living beings or even inanimate objects and systems), as well as human's relation to it and ethical and aesthetic issues resulting from the complexity of interdependencies and mutual interactions between human and nature. Most often, the problem of axiology conditions of the current ecological crisis is investigated by analysing the functioning value systems and their influence on human behaviour towards the natural environment, recognizing their fundamental values as the source of conflict between the anthroposphere and the biosphere.

Thus, evaluating the treatment of nature as well as technologies concerning the impact on the natural environment are becoming the subject for philosophizing more often. By becoming something not obvious, not permanent, uncertain and exhaustible, nature began to be treated as something necessary and desirable. It became a good and not only a valuable economic good, it was always that for humans, but also a good considered in ethical, esthetical and religious terms.

In close connection and based on the decisions made within the issue of "nature axiologisation" and its processing by a human, the issues of human's attitude towards nature in terms of moral good and evil, duty and responsibility are addressed, which usually involves various proposals for creating environmental ethics.
3. The next topics of interests are the analyses concerning disturbances or even collapse of current forms and ways of expressing relations and interactions between nature and human, what is commonly referred to as the ecological crisis or the biosphere crisis. From the philosophical point of view, one would reflect on three aspects of this relations: a) "metaphysical-existential", concerning such a transcendence of nature (expression of humanity) that will allow preserving the existence and identity of human and the biosphere (the problem of further possibilities or limits of the human pursuit of "being something more"); b) civilizational-social, contesting the axiological foundations of the current direction of the development of civilization of the globalized humanity; c) existential-natural, a threat to further existence of a human as a species.

Aiming to grasp the essence, causes and main conditions of this crisis, one addresses the issue of the contradiction between the contemporary dominant direction of civilizational development and the finiteness of the Earth (the biosphere) and its resources. A vital and yet to be researched issue is the disproportion between the scale, depth and pace (continuous acceleration) of changes made by human in nature and the evolutionary mechanisms of compensating for disturbances in ecosystems and the biosphere. In this context, various possibilities of overcoming the crisis are considered and a vision of a society developing in harmony with the natural environment is sought, focusing primarily on axiological issues.

4. Another group of problems of ecophilosophy, which are of great importance but are relatively rarely addressed and perhaps least associated with the efforts for understanding of the relationship between human and nature, are issues related to the analysis of different forms of organizing social order, current structures of political life, economic activity, cultural patterns and ideologies dominant in society and politics in terms of their place and role in creating the "human (society) - nature" system. The point is, researching the factors determining the "social 
forming" of nature. And also, the impact of the changes in the biosphere on social processes, forms, structures and contents of social life, economic change, etc. These questions are addressed in close connection with axiological and "crisisology" issues, but the social, political, ideological and economic conditions and consequences of interactions between human and the biosphere remain the focal point. Particularly important are the analyses of the foundations of the current philosophy of nature management and search for a common denominator for the integration of economic criteria and natural requirements (criteria) concerning economic activity and, as a consequence, common performance indicators. This involves revising and perhaps abandoning the traditional paradigm of economic thinking and searching for new axiological justifications for the emerging distinct economic theory - ecological economics, which assumes the necessity of integrating economics and ecology.

5. Recently, more often, one addresses issues concerning the place and role of nature in the individually grasped and existentially evaluated experiencing of the world, the problems of an "ecological lifestyle", the analysis of one's own way of life and behaviour and the relationship with the natural environment in terms of their impact on the quality one's life, satisfaction, health, happiness, etc. The question of the pursuit to harmonize individual life with nature is considered as the meaning and purpose of life, the source of happiness and the way of self-fulfilment, which might prove that the individual self is connected to the natural environment, while the full self-fulfilment requires "consciousness-raising", identification with expanding human and natural community circles. In this context, the connections and dependencies between disinterested contemplation of nature, proper diet, hygiene, etc. and clarity, way of thinking, respect for moral principles, satisfaction and happiness, are considered.

In these considerations, one often refers to philosophical and religious practices and thoughts of the Far East. One might include such issues to the private ego-ecosophy if not for the fact that their contents and results are published, disseminated in the mass media, and function in the social consciousness.

Although the issues presented do not exhaust the field of discussion of the ecophilosophy, one might say that they dominate it and outline its scope. It is obvious that its scope is constantly changing as a result of the development of natural sciences, growing problems between human and nature, civilizational, cultural and political changes taking place in an increasingly globalized world. I have not presented the concepts, theses and solutions to problems formulated based on various schools of thought. - I shall present these another time. What I meant here, as when I tried to show the specificity of the subject of ecophilosophy, was to outline the scope of the dominant issues characteristic for this new field of philosophy.

\section{Future prospects}

Reading numerous publications on the presented issues encourages me to formulate some general remarks on the current status of ecophilosophy, on what it really is, what it should be, how it should not be understood and practised.

Therefore, ecophilosophy is a consequence of the increasingly severe experienced and existentially important problems of human (society, the human race) with nature. This includes mainly practical problems, manifesting themselves in the global environmental crisis and heralding the possibility of self-destruction of species. Also, theoretical problems resulting from the questioning, at the end of the 20th century, of many views and beliefs that have so far been taken for granted. For example:

- a belief of the fundamental "otherness" of human, his uniqueness and autonomy, as well as the possibility of forming and shaping the sphere of one's own life;

- a belief of human monopoly on the possession of consciousness and thoughts;

- a belief in the inexhaustibility of nature and its resources and that there will always be enough for us; 
- a conviction about the possibility of objective, axiologically neutral cognition of nature;

- a belief in the ethical neutrality of human actions in nature and moral neutrality of technology and economic activity.

From this perspective, ecophilosophy means searching for a different, new theory that would explain the relations and interactions between human and nature, creating a new categorical network to grasp the essence and meaning of these relations and interactions. Concepts and deliberations formulated and presented within ecophilosophy most often focus on:

- efforts for understanding and "localizing" of nature in the context of (structure of living human) everything that somehow exists, its ontological and axiological characteristics in terms of the social and mental sphere (based on ontological and metaphysical assumptions);

- search for such an understanding of human that will explain human in every dimension of its existence and functioning in his relation with nature;

- evaluation of value and usefulness of scientific knowledge and other types of cognition in terms of the possibility of obtaining essential for life and cognitive knowledge on human interactions with the natural environment, selection of methods of achieving such knowledge and achieving "ecological wisdom";

- creation of a new "ecological axiology", understanding ecological values and its hierarchies, systematization, etc.

By covering the sphere of theoretical thinking, ecophilosophy is at the same time (or perhaps essentially) a practical philosophy (in the Aristotelian meaning). That is the case, because:

- it aims to understand human co-existence in nature (active co-existence on a global scale that alters nature profoundly and gradually faster), in terms of the effect of human activity on well-being of human and functioning of the biosphere;
- most of the direction of ecophilosophy propose and postulate the implementation of such directives of behaviour and action that will respect the more or less radical "nature-centric" hierarchy of values. Therefore, from the perspective of "humanistic bio-centrism" it aims to determine which actions are acceptable, which goals are fair and it formulates specific rules and standards of behaviour;

- it aspires to be not only an intellectual cognition but also, or primarily, a testimony to its co-existence with nature that today is largely "humanized". It aspirates to be the art of living, or according to some, the art of survival;

- it postulates "wisdom" orienting of philosophizing in understood as the pursuit of wisdom that allows one to improve their life quality.

And therefore, if ecophilosophy is to be more than just a fad and it aims to enter the family of philosophical disciplines permanently, it should not or cannot allow being perceived as:

- only the creed of a "green" faith, an irrevocable and unordered rationally articulation of emotionally charged, "deep" beliefs, a new "Gospel";

- ideology, a political agenda, although it may constitute a theoretical foundation of one;

- knowledge of the environment, its conservation or humanistic aspects of Environmental protection;

- only environmental (ecological) ethics or bioethics in general;

- exclusively humanistic ecology or human ecology.

Every philosophy is a human creation, so it is always reflected as human belonging to the world, more or less active participation in its affairs, and is written from within it. The ecophilosophy is no different, as the name suggests that it focuses on relations with the natural environment, it does so to find an axiological basis for understanding and giving meaning to human life. One or the other, or a little bit of everything. Without giving up research aspirations and being 
aware of the inevitability of co-creation of nature in its cognition and the impossibility of transcending beyond perception imposed on us by human nature, one is guided by "anthropological care": the knowledge of relations with nature and its "axiologisation" are needed for a human to improve quality of life, or even to be able to live at all. Thus, ecophilosophy shows its anthropological dimension, it is yet another, modern philosophy of life.

\section{Bibliography}

Bartkowski, Tadeusz. 1991. Ksztattowanie i ochrona środowiska człowieka. Warszawa: Państwowe Wydawnictwo Naukowe.

Dołęga, Józef M. 2005. „Ekofilozofia i nauki środowiskowe na początku XXI wieku." Szkice humanistyczne 5(3-4): 251-266.

Kotarbiński, Adam. 1977. Zasady tworzenia pojęć $i$ nazw do systemowego kształtowania środowiska. Warszawa: Wydawnictwo Katalogów i Cenników.

Tyburski, Włodzimierz. 1996. Ekofilozofia i bioetyka. Toruń: Wydawnictwo Top Kurier. 